\footnotetext{
${ }^{1}$ Department of Biological Bases of Animal Production, University of Agriculture, Lublin, Poland

${ }^{2}$ Institute of Genetics and Animal Breeding, Polish Academy of Sciences, Jastrzębiec, Poland
}

\author{
BRYGIDA ŚLASKA ${ }^{1}$ ， GRAŻYNA JEŻEWSKA ${ }^{1}$, GRZEGORZ ZIĘBA ${ }^{1}, \quad$ MARIUSZ \\ PIERZCHAŁA ${ }^{2}$
}

\title{
Genetic variability and linkage of selected microsatellite markers in the Chinese raccoon dog (Nyctereutes procyonoides procyonoides)
}

\begin{abstract}
The aim of the recent study was to analyze the variability and linkage study of selected microsatellite markers of the Chinese raccoon dog (Nyctereutes procyonoides procyonoides) bred in Poland. In general, 3 generations of animals maintained at the Polish breeding farm, were under observation. For this project, the variability of 20 canine microsatellite loci was examined in the raccoon dog. The number of alleles, frequencies, and the statistics that express polymorphism, the position of markers, the distance between them as well as the linkage analysis among the analyzed loci were determined. Altogether, there were 74 alleles identified. Three of the microsatellites studied displayed a monomorphic allele. The total number of other alleles per locus varied from 2 to 6 . An average allele number of polymorphic loci was 4.4 alleles per one locus. An average PIC value was 0.49 . The linkage analysis concerned 17 polymorphic markers. Five linkage groups were identified, ranging in size from 36.3 to 120.7 cM. The largest linkage groups contained 5 markers each, and the smallest -2 markers. The sex-averaged linkage groups comprised 17 markers. The total coverage was $380.3 \mathrm{cM}$, with intervals between markers ranging from 6.7 to 43.5 cM; the average distance between markers was 31.69 cM. Two of the linkage groups exceeded $100 \mathrm{cM}$ in length. The construction of the genetic map of the Chinese raccoon dog, is the first step to identify the genes with a major effect (quantitative trait loci, QTL), which as a result can be beneficial in breeding work undertaken on breeding farms.
\end{abstract}

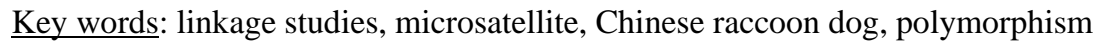

\section{Zusammenfassung}

Titel der Arbeit: Genetische Variabilität und Koppelungsanalyse ausgewählter Mikrosatellitenmarker beim Marderhund (Nyctereutes procyonoides procyonoides)

Ziel der Untersuchungen war die Analyse der Variabilität sowie eine Koppelungsanalyse ausgewählter Mikrosatellitenmarker beim in Polen gezüchteten Marderhund (Nyctereutes procyonoides procyonoides). Untersucht wurden 3 Generationen von Tieren aus einer der Zuchtfarmen im südöstlichen Polen. In der Arbeit wird die Variabilität von 20 Mikrosatelliten-Loci beim Marderhund dargelegt. Während der Untersuchungen wurden bestimmt: Länge, Anzahl und Häufigkeiten der Allele im Bereich der einzelnen Mikrosatelliten-Loci, Reihenfolge der Markerpositionen, Abstand zwischen den Markerpositionen und eine Analyse der Koppelungen zwischen den analysierten Loci durchgeführt. Insgesamt wurden 74 Allele identifiziert. Drei der analysierten Loci waren monomorph. An den übrigen Loci schwankte die Zahl der Allele zwischen 2 und 6. Durchschnittlich betrug die Zahl der polymorphen Allele eines Loci 4.4 Allele pro Locus. Der PIC betrug durchschnittlich 0.49. Von der Koppelungsanalyse wurden 17 polymorphe Marker erfasst. Es wurden 5 Koppelungsgruppen mit einer Länge von 36.3 bis 120.7 cM identifiziert. Die größte Koppelungsgruppe bestand aus 5 Markern und die kleinste aus 2 Markern. Durchschnittlich setzten sich die Koppelungsgruppen für beide Geschlechter aus 17 Markern zusammen und deckten 380.3 cM ab, mit Abständen zwischen den Markern von 6.7 bis 43.5 cM; der Abstand zwischen den Markern betrug durchschnittlich 31.69 cM. Die genetische Kartierung des Marderhunds ist der erste Schritt auf dem Weg zur Identifizierung der sog. "quantitative trait loci" (QTL), die quantitativen Merkmalen zugrunde liegen und bei der Zuchtarbeit in Zuchtfarmen genutzt werden können. 
Introduction

Microsatellite sequences belong to one of the most often used markers, due to their high polymorphism, codominance and many other useful properties. The access to information of the domestic dog (Canis familiaris) genome, made possible the investigations of different species belonging to Canidae. The homology of the DNA sequence make it possible for most of the primers used in PCR amplification for the canine Canis familiaris microsatellites to be successfully applied to the arctic fox (Alopex lagopus), red fox (Vulpes vulpes) and the Chinese raccoon dog (Nyctereutes procyonoides procyonoides) genome studies (FREDHOLM and WINTERO 1995, KLUKOWSKA et al. 2002, 2003, ŚLASKA et al., 2005). Moreover, canine-derived cosmid probes are useful for physical mapping of microsatellite loci in above-mentioned Canidae species (ROGALSKANIZNIK et al. 2003, SZCZERBAL et al., 2003, YANG et al. 2000).

Currently certain studies are aimed to build the basis for mapping the genomes of other species belonging to Canidae (red fox, arctic fox and Chinese raccoon dog). The main goal is to localize genes affecting their breeding and economic value, manifested in skin production. The previous studies of microsatellite loci showed the high DNA sequence conservation inside the Canidae family (FREDHOLM and WINTERO 1995). Such conservation is the basis for building physical and genetic maps of red fox and arctic fox animals belonging to the Canidae family with the use of Canis familairis data (KLUKOWSKA et al. 2002).

A linkage map of the canine genome is being mainly developed in the frame of international collaboration, named as DogMap project (LINGAAS et al. 1997). Many studies showed an increase in genetic marker density localized in the canine genome, (MELLERSH et al. (1997, 2000), WERNER et al. (1999), NEFF et al. (1999), JÓNASDÓTTIR et al. (1999), LINGAAS et al. (2001), BREEN et al. (2001, 2004), GUYON et al. (2003) and HITTE et al. (2005)).

The Chinese raccoon dog as one of the canine family belonging species is also one of the fur-bearing animals kept on farms. Currently the genome map of this species is far from completion, whereas a detailed genetic map would be highly beneficial for identifying important genes that influence functional and conformational traits.

The physical map of Chinese raccoon created on the basis of Canis familiaris data was presented in studies published by: NIE et al. (2003), ROGALSKA-NIZNIK et al., (2003), SZCZERBAL et al. (2003, 2007). ŚLASKA et al. (2005) successfully amplified the chosen DNA fragment of Chinese raccoon dog on the basis of primer sequences and conditions of PCR amplification taken from Canis familiaris data. So far, no comprehensive meiotic linkage map of the Chinese raccoon dog has been found in the accessible literature. Detection of the genetic markers and linkage analysis between them are very important. The construction of the genetic map of the raccoon dog is the first step for further studies aimed to localize the genes with a major effect (quantitative trait loci, QTL). In breeding work based on genetic markers we can improve the selection program undertaken on breeding farms. 
The aim of the recent study was to analyze the variability and linkage study of the selected microsatellite markers of the Chinese raccoon dog (Nyctereutes procyonoides procyonoides) bred in Poland.

\section{Materials and methods}

In general, 3 generations of the Chinese raccoon dog (altogether 208 animals) maintained at the Polish breeding farm in the years 2002-2004 were under observation (Table 1). Altogether, 6 raccoon dog families were genotyped, with each generation $\mathrm{F}_{0}$ male mating with 2-3 females bred in the farm (Table 1), which resulted in 20.2 individuals on average in generation $\mathrm{F}_{2}$.

Table 1.

The structure of the families (Familienstruktur)

\begin{tabular}{|c|c|c|c|c|c|c|c|}
\hline \multirow{3}{*}{ Family } & \multicolumn{6}{|c|}{ Generation } & \multirow{3}{*}{ Total } \\
\hline & \multicolumn{2}{|l|}{$\mathrm{F}_{0}$} & \multicolumn{2}{|l|}{$\mathrm{F}_{1}$} & \multicolumn{2}{|l|}{$\mathrm{F}_{2}$} & \\
\hline & Male & Female & Male & Female & Male & Female & \\
\hline 1 & 1 & 2 & 5 & 5 & 12 & 8 & 33 \\
\hline 2 & 1 & 3 & 5 & 5 & 11 & 10 & 35 \\
\hline 3 & 1 & 3 & 7 & 7 & 10 & 10 & 38 \\
\hline 4 & 1 & 3 & 3 & 3 & 9 & 9 & 28 \\
\hline 5 & 1 & 3 & 6 & 6 & 14 & 8 & 38 \\
\hline 6 & 1 & 3 & 6 & 6 & 9 & 11 & 36 \\
\hline
\end{tabular}

Genomic DNA was isolated from blood using QIAamp DNA Blood Mini Kit (QIAGEN). 20 microsatellites (FH3922; FH3300; C01.246; REN112I02; REN288J16; PEZ17; REN144A06; FH2097; REN126G20; AHT103; C03304; ACE; FH2263; FH3596; REN198P23; UOR0442; FH2295; REN230G12; REN01N09; BAC_382-K19), located on four chromosomes in Canis familiaris, were used in the present study. All the primers as well as conditions of PCR (Polymerase Chain Reaction) amplification of microsatellite sequences were taken from literature about the domestic dog genome (Canis familiaris) (GUYON et al., 2003; BREEN et al., 2001; NEFF et al., 1999; HOLMES et al., 1995; YUZBASIYAN-GURKAN et al., 1997; JOUQUAND et al., 2000) and modified by ŚLASKA et al. (2005). The allele identification of the sequences of microsatellite loci was conducted by capillary electrophoresis performed on the sequencer - ABI PRISM ${ }^{\mathrm{TM}}$ 3100-Avant Genetic Analyzer and analyzed using 3100-AVANT ABI PRISM DATA COLLECTION and GENE MAPPER SOFTWARE 3.5. Polymorphism information content - PIC was computed according to the formula elaborated by BOTSTEIN et al. (1980). Linkage analyses were performed using the CRI-MAP program package, version 2.4 (Green et al., 1990). All pairwise combinations of markers were first analyzed by the twopoint option and LOD treshold of 3. Option BUILD was used to order markers in a linkage group. Option FLIPS was used to check optional orders between adjacent markers. The best map was based on the highest log 10 likelihood. The map was drawn with the MapChart software (VOORRIPS, 2002). The position of markers and distance between the analyzed loci in centiMorgans (cM) were presented. The linkage groups in this report are numbered LG01, LG02, etc. 


\section{Results}

Allele length and its frequency for individual microsatellite loci of the parental generation $\left(\mathrm{F}_{0}\right)$ of Chinese raccoon dogs are presented in Table 2. Altogether, 74 alleles for 20 microsatellite markers were identified. Three of the microsatellite loci studied (FH2263, UOR0442; FH2295) proved to be monomorphic.

The total number of other alleles per locus varied from 2 (REN126G20) to 6 (AHT103, REN01N09, BAC_382-K19). The average allele number of polymorphic loci was 4.4 allele per one locus.

Comparison of the allele frequencies between males and females in parental generation $\left(\mathrm{F}_{0}\right)$ of Chinese raccoon dogs demonstrates that in the majority of the cases they differed from each other (Table 2). The great variability of genetic groups is corroborated by the presence of specific alleles both in the females and the males. In the case of 9 loci (C03304, ACE, REN198P23, FH3300, C01.246, REN288J16, FH2097, REN01N09, and BAC_382-K19) in the parental generation of females, there were 11 alleles observed which did not occur in the male group; on the other hand, in 2 loci (REN126G20, REN230G12) there were 2 alleles specific exclusively for the males (Table 2). A different arrangement was observed for a five-allele locus C03304, at which the total frequency of two alleles, 104 bp and 114 bp, was over 80\% in the females, whereas the other alleles occurred rarely. A similar distribution was characteristic for locus REN288J16. Two variants, 84 bp and 98 bp, were predominantly distributed with frequency over $80 \%$ in females and over $90 \%$ in males. For a three-allele locus ACE, at which the total frequency allele 73 bp was $75 \%$ in the female and $64 \%$ in the male, the following regularity was observed: the longer alleles, the lower allele frequency.

Table 2

Characterization of frequency of alleles at selected microsatellite loci in parental generation $\left(\mathrm{F}_{0}\right)$ of Chinese raccoon dogs (Charakteristik der Allelfrequenz ausgewählter Mikrosatelliten-Loci in der Elterngeneration $\left(\mathrm{F}_{0}\right)$ von Marderhunden)

\begin{tabular}{lllll}
\hline Locus & $\begin{array}{c}\text { Alleles } \\
\text { length (bp) }\end{array}$ & Alleles (bp) & \multicolumn{2}{l}{ Frequency of alleles (\%) } \\
& 2 & 3 & 4 & Females \\
\hline 1 & $104-114$ & 104 & 0.28 & 0.17 \\
C03304 & & 106 & - & 0.07 \\
& & 108 & - & 0.05 \\
& & 110 & - & 0.05 \\
ACE & 114 & 0.72 & 0.66 \\
& $73-91$ & 73 & 0.64 & 0.75 \\
FH3596 & & 0.36 & 0.15 \\
& & 91 & - & 0.10 \\
& $188-208$ & 188 & 0.36 & 0.36 \\
REN198P23 & 192 & 0.43 & 0.36 \\
& & 196 & 0.07 & 0.05 \\
& & 208 & 0.14 & 0.23 \\
& $129-159$ & 129 & 0.28 & 0.14 \\
FH3922 & 131 & 0.33 & 0.43 \\
& & 155 & 0.17 & 0.19 \\
& & 157 & 0.22 & 0.12 \\
& & 159 & - & 0.12 \\
& & 334 & 0.19 & 0.03 \\
& $334-342$ & 338 & 0.12 & 0.05 \\
& & 342 & 0.69 & 0.92 \\
\hline
\end{tabular}




\begin{tabular}{|c|c|c|c|c|}
\hline \multicolumn{5}{|c|}{ Table 2- cont. (Fortsetz.) } \\
\hline 1 & 2 & 3 & 4 & 5 \\
\hline \multirow[t]{3}{*}{ FH3300 } & $215-235$ & 215 & 0.50 & 0.61 \\
\hline & & 227 & 0.50 & 0.38 \\
\hline & & 235 & - & 0.01 \\
\hline \multirow[t]{4}{*}{ C01.246 } & $114-130$ & 114 & 0.43 & 0.32 \\
\hline & & 116 & 0.07 & 0.03 \\
\hline & & 118 & 0.50 & 0.62 \\
\hline & & 130 & - & 0.03 \\
\hline \multirow[t]{3}{*}{ REN112I02 } & $236-252$ & 236 & 0.50 & 0.67 \\
\hline & & 246 & 0.40 & 0.28 \\
\hline & & 252 & 0.10 & 0.05 \\
\hline \multirow[t]{5}{*}{ REN288J16 } & 84-98 & 84 & 0.50 & 0.71 \\
\hline & & 86 & - & 0.10 \\
\hline & & 90 & 0.06 & 0.05 \\
\hline & & 96 & - & 0.02 \\
\hline & & 98 & 0.44 & 0.12 \\
\hline \multirow{5}{*}{ PEZ17 } & $196-212$ & 196 & 0.22 & 0.13 \\
\hline & & 200 & 0.11 & 0.16 \\
\hline & & 204 & 0.44 & 0.55 \\
\hline & & 208 & 0.17 & 0.13 \\
\hline & & 212 & 0.06 & 0.03 \\
\hline \multirow[t]{3}{*}{ REN144A06 } & 138-144 & 138 & 0.50 & 0.57 \\
\hline & & 140 & 0.37 & 0.33 \\
\hline & & 144 & 0.13 & 0.10 \\
\hline \multirow[t]{5}{*}{ FH2097 } & $280-296$ & 280 & 0.25 & 0.10 \\
\hline & & 284 & 0.06 & 0.17 \\
\hline & & 288 & 0.50 & 0.57 \\
\hline & & 292 & 0.19 & 0.13 \\
\hline & & 296 & - & 0.03 \\
\hline \multirow[t]{2}{*}{ REN126G20 } & $110-116$ & 110 & 0.93 & 1.00 \\
\hline & & 116 & 0.07 & - \\
\hline \multirow[t]{6}{*}{ AHT103 } & $68-82$ & 68 & 0.06 & 0.14 \\
\hline & & 70 & 0.28 & 0.17 \\
\hline & & 72 & 0.32 & 0.43 \\
\hline & & 76 & 0.11 & 0.07 \\
\hline & & 80 & 0.06 & 0.05 \\
\hline & & 82 & 0.17 & 0.14 \\
\hline \multirow[t]{3}{*}{ REN230G12 } & $370-376$ & 370 & 0.75 & 0.85 \\
\hline & & 372 & 0.19 & 0.15 \\
\hline & & 376 & 0.06 & - \\
\hline \multirow[t]{6}{*}{ REN01N09 } & 139-163 & 139 & - & 0.05 \\
\hline & & 141 & 0.06 & 0.16 \\
\hline & & 143 & 0.21 & 0.23 \\
\hline & & 145 & 0.56 & 0.38 \\
\hline & & 159 & 0.11 & 0.09 \\
\hline & & 163 & 0.06 & 0.09 \\
\hline \multirow[t]{6}{*}{ BAC_382-K19 } & $124-150$ & 124 & 0.28 & 0.15 \\
\hline & & 130 & 0.28 & 0.11 \\
\hline & & 132 & 0.27 & 0.30 \\
\hline & & 136 & 0.11 & 0.23 \\
\hline & & 144 & - & 0.07 \\
\hline & & 150 & 0.06 & 0.14 \\
\hline
\end{tabular}

The polymorphism level in the parental generation of Chinese raccoon dogs is presented in Table 3. Average PIC value was 0.50 and 0.47 for males and females, respectively. The highest PIC value in the males from generation $\mathrm{F}_{0}$, approximately 0.7 , was reported for AHT103, BAC_382-K19, REN198P23 and PEZ17, whereas in the females PIC values exceeding 0.7 were observed for BAC_382-K19, REN01N09 and AHT103. 
Table 3

Characterization of polymorphism at selected microsatellite loci in parental generation $\left(\mathrm{F}_{0}\right)$ of Chinese raccoon dogs (Charakteristik des Polymorphismus ausgewählter Mikrosatelliten-Loci in der Elterngeneration $\left(\mathrm{F}_{0}\right)$ von Marderhunden)

\begin{tabular}{lllll}
\hline Locus & Males & & Females \\
& $\begin{array}{l}\text { Number of } \\
\text { alleles }\end{array}$ & $\begin{array}{l}\text { Parental } \\
\text { PIC }\end{array}$ & $\begin{array}{c}\text { Number of } \\
\text { alleles }\end{array}$ & $\begin{array}{l}\text { Parental } \\
\text { PIC }\end{array}$ \\
\hline C03304 & $\mathbf{2}$ & 0.32 & $\mathbf{5}$ & 0.48 \\
ACE & $\mathbf{2}$ & 0.35 & $\mathbf{3}$ & 0.37 \\
FH3596 & $\mathbf{4}$ & 0.60 & $\mathbf{4}$ & 0.62 \\
REN198P23 & $\mathbf{4}$ & 0.69 & $\mathbf{5}$ & 0.70 \\
FH3922 & $\mathbf{3}$ & 0.43 & $\mathbf{3}$ & 0.14 \\
FH3300 & $\mathbf{2}$ & 0.38 & $\mathbf{2}$ & 0.36 \\
C01.246 & $\mathbf{3}$ & 0.47 & $\mathbf{4}$ & 0.42 \\
REN112I02 & $\mathbf{3}$ & 0.49 & $\mathbf{3}$ & 0.40 \\
REN288J16 & $\mathbf{3}$ & 0.46 & $\mathbf{4}$ & 0.43 \\
PEZ17 & $\mathbf{5}$ & 0.67 & $\mathbf{5}$ & 0.60 \\
REN144A06 & $\mathbf{3}$ & 0.51 & $\mathbf{3}$ & 0.47 \\
FH2097 & $\mathbf{4}$ & 0.59 & $\mathbf{5}$ & 0.57 \\
REN126G20 & $\mathbf{2}$ & 0.12 & $\mathbf{1}$ & 0.00 \\
AHT103 & $\mathbf{6}$ & 0.73 & $\mathbf{6}$ & 0.71 \\
REN230G12 & $\mathbf{3}$ & 0.35 & $\mathbf{2}$ & 0.22 \\
REN01N09 & $\mathbf{5}$ & 0.58 & $\mathbf{6}$ & 0.72 \\
BAC_382-K19 & $\mathbf{5}$ & 0.71 & $\mathbf{6}$ & 0.77 \\
\hline
\end{tabular}

\section{Linkage study of selected genetic markers}

Till now, the results of the genetic linkage map for the Chinese raccoon dog have not been presented in the literature. The present study is the first to demonstrate the linkage between genetic markers analysed in Chinese raccoon.

For the linkage analysis 17 polymorphic markers were chosen, which were linked with $6.69 \geq \mathrm{LOD} \geq 3.01$ in five linkage groups, in the range from 36.3 to $120.7 \mathrm{cM}$ (Table 4, Figure 1).

The number of informative meioses in the experiment were from 25 (REN126G20) to 313 (BAC_382-K19). The largest group contained 5 markers each (LG01, LG02), the smallest - 2 markers each (LG03, LG04). The distance between 17 markers for sex-averaged linkage maps are presented in Table 4 and Figure 1. The total map coverage $380.3 \mathrm{cM}$, with intervals between the markers ranged from 6.7 to $43.5 \mathrm{cM}$ (Table 4); the average distance between the markers was estimated as $31.69 \mathrm{cM}$. Two of the groups of the linkage analysis, LG01 and LG02, exceeded 100 cM in length (120.7 and 100.2, respectively). Differences in recombination rates between the sexes were observed. The total female map length was $363.2 \mathrm{cM}$, whereas the male map length was $512.1 \mathrm{cM}$. The female map was shorter than that of male in linkage groups LG01, LG02 and LG04, but longer in LG03 and LG05. In most cases, the observed male recombination rate was higher than that of female. 
Table 4

Sex-averaged linkage groups (LG) in the Chinese raccoon dog (Koppelungsgruppen (LG) beim Marderhund, durchschnittlich für beide Geschlechter )

\begin{tabular}{|c|c|c|c|c|c|}
\hline Linkage group & Locus & $\begin{array}{l}\text { Number of } \\
\text { informative } \\
\text { meioses }\end{array}$ & Recombination fraction & $\begin{array}{l}\text { Distance between } \\
\text { loci (cM) }\end{array}$ & $\begin{array}{l}\text { Order of markers } \\
\text { arrangement (cM) }\end{array}$ \\
\hline \multirow[t]{9}{*}{ LG01 } & REN112I02 & 229 & & & 0.0 \\
\hline & & & 0.27 & 29.9 & \\
\hline & FH3922 & 122 & & & 29.9 \\
\hline & & & 0.20 & 21.0 & \\
\hline & REN288J16 & 246 & & & 50.8 \\
\hline & & & 0.35 & 42.8 & \\
\hline & FH3300 & 39 & & & 93.6 \\
\hline & & & 0.25 & 27.1 & \\
\hline & C01.246 & 203 & & & 120.7 \\
\hline \multirow[t]{9}{*}{ LG02 } & REN144A06 & 244 & & & 0.0 \\
\hline & & & 0.33 & 38.8 & \\
\hline & PEZ17 & 267 & & & 38.8 \\
\hline & & & 0.07 & 6.7 & \\
\hline & FH2097 & 258 & & & 45.5 \\
\hline & & & 0.29 & 33.0 & \\
\hline & AHT103 & 285 & & & 78.5 \\
\hline & & & 0.20 & 21.7 & \\
\hline & REN126G20 & 25 & & & 100.2 \\
\hline \multirow[t]{3}{*}{ LG03 } & C03304 & 161 & & & 0.0 \\
\hline & & & 0.31 & 36.3 & \\
\hline & REN198P23 & 292 & & & 36.3 \\
\hline \multirow[t]{3}{*}{ LG04 } & FH3596 & 87 & & & 0.0 \\
\hline & & & 0.34 & 40.6 & \\
\hline & ACE & 203 & & & 40.6 \\
\hline \multirow[t]{5}{*}{ LG05 } & BAC_382-K19 & 315 & & & 0.0 \\
\hline & & & 0.35 & 43.5 & \\
\hline & REN230G12 & 133 & & & 43.5 \\
\hline & & & 0.33 & 39.0 & \\
\hline & REN01N09 & 312 & & & 82.5 \\
\hline
\end{tabular}

Discussion

The initial stage of the physical map of the Chinese raccoon dog genome was presented in studies by SZCZERBAL et al. (2003), where altogether thirty-five loci had already been physically localised on chromosomes. But these markers were different to those presented in our work. This makes our results comparable only with the results obtained for Canis familiaris. Such an approach could be justified because both of the species belong to one family- Canidae. The genetic distance between Canis familiaris and the Chinese raccoon dog is relatively small and it facilitates the use of primers designed for amplification of particular fragments of domestic dog DNA. Most primers designed in this way were 


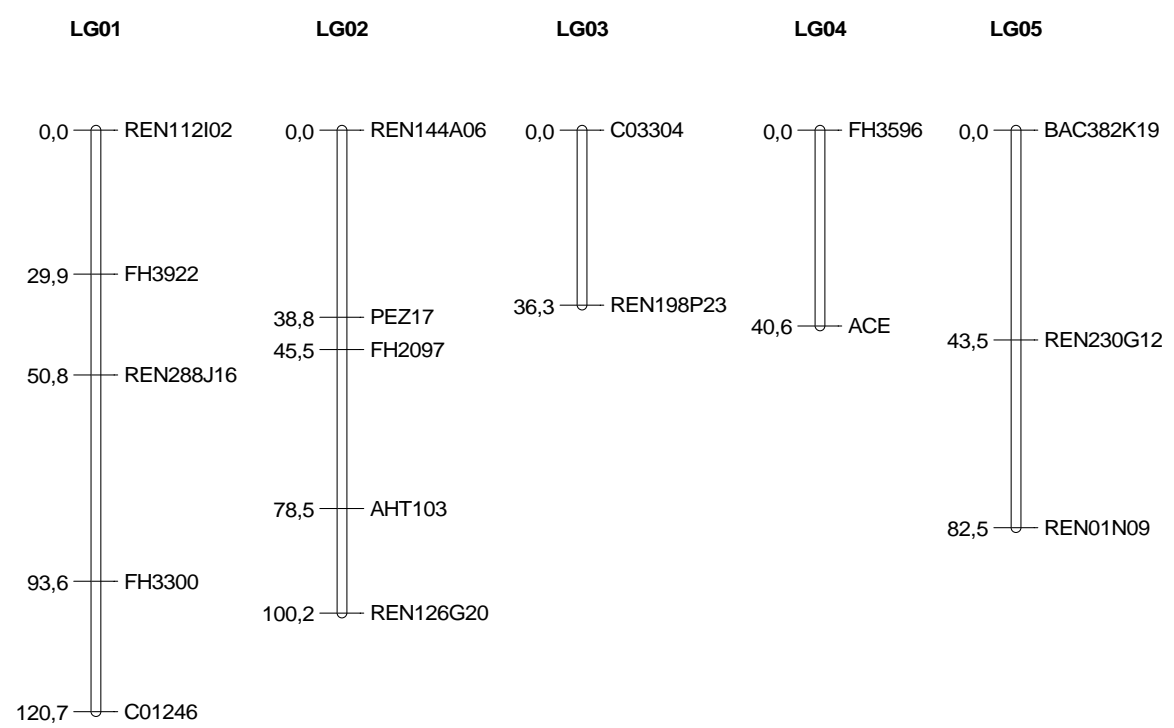

Fig. 1

Sex-averaged linkage groups in the Chinese raccoon dog (genetic distance in centiMorgan (cM) is presented). (Koppelungsgruppen beim Marderhund, durchschnittlich für beide Geschlechter (Genetische Distanz in centiMorgan [cM])).

successfully applied in our studies. Such an approach was previously successfully applied in other species from Canidae family (NIE et al. 2003, ROGALSKA-NIZNIK et al., 2003, SZCZERBAL et al., 2003, ŚLASKA et al., 2005). However the length of the amplified fragment and the number of alleles for particular loci were different for the dog and the Chinese raccoon dog. The results of the studies carried out by CLARK et al. (2004) show also that the number of microsatellite alleles was considerably divergent depending on the breed of the domestic dog. For example, the number of alleles for microsatellite FH2263 identified in different breeds such as Boykin Spaniel, German Shepherd and Shetland Sheepdog were 11, 12 and 9 respectively, only in Collie this loci displayed two alleles. In our investigations of the Chinese raccoon dog that marker proved to be monomorphic. The results of the present study introduce new information to the knowledge about the Chinese raccoon dog genome as well as domestic dog genetic markers (GUYON et al., 2003; BREEN et al., 2001; NEFF et al., 1999; HOLMES et al., 1995; YUZBASIYAN-GURKAN et al., 1997; JOUQUAND et al., 2000, CLARK et al., 2004). These results show that the alleles of particular loci in our study (Table 2) were in the majority of cases similar for the dog and the raccoon dog. Based on the obtained results it can be suggested that there is a 2-nucleotide repetitive motif in particular microsatellites (C03304, ACE, REN198P23, C01.246, REN288J16, REN144A06, AHT103, REN230G12, REN01N09, and BAC_382-K19) (Table 2); as far as others are concerned, it is essential to determine the DNA sequence. The conservation of the DNA sequence, which allowed amplification based on PCR starters designed for dog DNA, indicates that, presumably, the repetitive motif is conservative, too. Obviously, in order to determine the sequence of the repetitive motif it is crucial to conduct sequencing. 
Till now linkage analysis based on genetic markers for the Chinese raccoon dog have never been presented. These results can only be compared with the results obtained for Canis familiaris, because these markers have already been studied in the dog genome.

The markers in our study were grouped similarly to those for Canis familiaris.

On the basis of the results obtained from linkage analysis, the markers in our study were grouped in following order: Table 4, Figure 1.

This shows that for both species the markers were placed in the same groups. Loci from LG01 in the raccoon dog are placed on chromosome 1 of the domestic dog (CFA1), and markers from groups LG02 and LG05 are in the dog on CFA4 and CFA15 respectively. Markers from groups LG03 and LG04 are in the dog on CFA9 (GUYON et al., 2003; BREEN et al., 2001; NEFF et al., 1999; HOLMES et al., 1995; YUZBASIYANGURKAN et al., 1997; JOUQUAND et al., 2000), so it is possible that linkage groups LG03 and LG04 are on the same chromosome in the raccoon dog. At the beginning in the frame of DogMap project activity there were altogether 94 genetic markers genotyped. For our studies only one - AHT103 showed usefulness. The following genetic linkage map of the Canine genome has been developed by typing 150 microsatellite markers grouped in 30 linkage groups (MELLERSH et al., 1997). From those results we chose also only one useful in our analysis- FH2097. The next canine linkage map according to WERNER et al. (1999), included already 341 mapped markers distributed over 38 linkage groups. In that study the canine linkage group 2 consisted of the same three markers as those used in our study and they were ordered as follows: FH2097, AHT103, PEZ17, but the distances between the loci were smaller (0.6 cM and $1.6 \mathrm{cM}$ respectively) in comparison to those obtained for the Chinese raccoon dog (Table 4, Figure 1). WERNER et al. (1999) qualified the position of another two markers studied in the present work (C01.246 - CFA1; FH2263 - CFA9). NEFF et al. (1999) reported the canine linkage map with the number of mapped loci expanded to 276. In both mentioned studies the presented canine linkage group including FH2097 and AHT103 markers as well as AHT103 and PEZ17 21 markers were arranged in the same order, but in comparison to our results, the distances between the loci were smaller. Another study (LINGAAS et al., 2001) presented a genetic linkage analysis with 39 linkage groups using 222 polymorphic canine markers based on typing in the International DogMap reference families. In that study 187 of the 222 loci were assigned to 39 different linkage groups. They presented the position of two markers: FH2097 and AHT103 in linkage group L40. In the present study the distance between these two microsatellite loci was bigger (Table 4, Figure 1).

MELLERSH et al. (2000) published the integration map of 724 markers. The next version of the comprehensive map, containing a total of almost 1800 markers was published by BREEN et al. (2001). GUYON et al. (2003) presented a comprehensive radiation hybrid map of the canine genome composed of 3270 markers. A recent integrated marker FISH/RH map of the dog includes 4249 genetic markers (BREEN et al. 2004). HITTE et al. (2005) described a detailed comparative map containing about 10.000 canine markers. Comparing positions of individual loci on comparative and radiation hybrid map in the dog (BREEN et al. 2004, GUYON et al. 2003, HITTE et al. 2004) and linkage groups in 
the Chinese raccoon dog (Table 4, Figure 1), there were differences observed in the order of their arrangement among the species.

The total female map in our experiment was shorter than the male map. The female map in the Chinese raccoon dog was shorter than that of male in linkage groups LG01, LG02 and LG04. This observation is in agreement with what has been observed in Canis familiaris (CFA5, L18, L26, L28, L32, L33, L36) (NEFF et al. 1999). The female map in the Chinese raccoon dog was longer than that of males in linkage groups LG03 and LG05. This study is consistent with the observations in other species, including humans (GYAPAY et al. 1994) and Canine (MELLERSH et al. 1997), where the recombination rate was higher in females than in males.

The results obtained show usefulness of the genetic information taken from other species from the same Canidae family in performing genetic analysis in the little-known Chinese raccoon dog genome.

The variability of 20 canine microsatellite loci was determined for the Chinese raccoon dog. The position of markers, the distance between them as well as the linkage analysis among the analyzed loci were worked out on the basis of meiotic linkage study in the Chinese raccoon dog, so in the study the first Nyctereutes procyonoides procyonoides linkage map was constructed. This might be the first step in highly beneficial identification of important genes that influence functional and conformation traits in the Chinese raccoon dog; such information may contribute as a valuable tool for selection.

\section{Acknowledgement}

This study was carried out within a research project financed by the Ministry of Scientific Research and Information Technology in years 2004-2006, grant no. 2 P06D 00626.

\section{References}

BOTSTEIN, D.; WHITE, R.L.; SKOLNICK, M.; DAVIS, R.W: Construction of a genetic linkage map in man using restriction fragment length polymorphism. Am. J. Hum. Genet. 32 (1980) 314-331

BREEN, M.; JOUQUAND, S.; RENIER, C.; MELLERSH, C.S.; HITTE, C.; HOLMES, N.G.; CHERON, A.; SUTER, N.; VIGNAUX, F.; BRISTOW, A.E.; PRIAT, C.; MCCANN, E.; ANDRE, C.; BOUNDY, S.; GITSHAM, P.; THOMAS, R.; BRIDGE, W.L.; SPRIGGS, H.F.; RYDER, E.J.; CURSON, A.; SAMPSON, J.; OSTRANDER, E.A.; BINNS, M.M.; GALIBERT, F.:

Chromosome-specific single-locus FISH probes allow anchorage of an 1800-marker integrated radiationhybrid/linkage amp of the domestic dog genome to all chromosome. Genome Res. 11 (2001), 1784-1795

BREEN, M.; HITTE, C.; LORENTZEN, T. D.; THOMAS, R.; CADIEU, E.; SABACAN, L.; SCOTT, A.; EVANNO, G.; PARKER, H.G.; KIRKNESS, E. F.; HUDSON, R.; GUYON, R.; MAHAIRAS, G. G.; GELFENBEYN, B.; FRASER, C. M.; ANDRE, C.; GALIBERT, F.; OSTRANDER E.A.: An integrated 4249 marker FISH/RH map of the canine genome. BMC Genomics, 5 (2004), 65

CLARK, L.A.; TSAI, K.L.; STEINER, J.M.; WILLIAMS, D.A. ; GUERRA, T. ; GALIBERT, F.; OSTRANDER, E.A. ; MURPHY, K.E. :

Chromosome-specific Microsatellite Multiplex Sets for Linkage Studies in the Domestic Dog. Genomics 84 (2004), 550-554

FREDHOLM, M.; WINTERO A.K.:

Variation of short tandem repeats within and between species belonging to the Canidae family. Mamm. Genome 6 (1995), 11-18 
GUYON R.; LORENTZEN T. D.; HITTE C.; KIM L.; CADIEU E.; PARKER H. G.; QUIGNON P.; LOWE J. K.; RENIER C.; GELFENBEYN B.; VIGNAUX F.; DEFRANCE H. B.; GLOUX S.; MAHAIRAS G. G.; ANDRE C.; GALIBERT F. ; OSTRANDER E. A.:

A 1-Mb resolution radiation hybrid map of the canine genome. Proc. Nat. Acad. Sci. USA 100:9 (2003), 5296-5301

GREEN, P.; FALLS, K.; CROOKS, S.; Documentation for CRI-MAP Version 2.4 (3/26/90) (1990)

GYAPAY, G.; MORISSETTE, J.; VIGNAL, A.; DIB, C.; FIZAMES, C.; MILLASSEAU, P.; MARC S.; BERNARDI, G.; LATHROP, M.; WEISSENBACH, J.: The 1993-94 Gènèthon human genetic linkage map. Nat. Genet. 7 (1994), 246-339

HITTE, C.; DERRIEN, T.; ANDRE, C.; OSTRANDER, E.A.; GALIBERT, E.:

CRH_Server: An online comparative and radiation hybrid mapping server for the canine genome. Bioinformatics 20 (2004), 3665-3667

HITTE, C.; MADEOY, J.; KIRKNESS, E.F.; PRIAT, C.; LORENTZEN, T.D.; SENGER, F.; THOMAS, D.; DERRIEN, T.; RAMIREZ, C.; SCOTT, C.; ET AL.:

Facilitating genome navigation: survey sequencing and dense radiation-hybrid gene mapping. Nat. Rev. Genet. 6 (2005), 643-648

HOLMES, N.G; DICKENS, H.F.; PARKER, H.L.; BINNS, M.M.; MELLERSH, C.S.; SAMPSON, J.: Eighteen canine microsatellites. Anim. Genet. 26 (1995), 132-133

JOUQUAND, S.; PRIAT, C.; HITTE, C.; LACHAUME, P.; ANDRÉ, C.; GALIBERT, F.: Identification and characterization of a set of 100 tri- and dinucleotide microsatellites in the canine genome. Animal Genetics, 31:4 (2000), 266-272

JÓNASDÓTTIR, T.J.; DOLF, G.; SLETTEN, M.; AARSKAUG, T.; SCHELLING, C.; SCHLÄPFER, J.; JOUQUAND, S.; PRIAT, C.; HOLMES, N.G.; LINGAAS, F.: Five new linkage groups in the canine linkage map. Anim. Genet. 30 (1999), 366-370

KLUKOWSKA, J.; STRABEL, T.; MACKOWSKI, M.; ŚWITONSKI, M.: Microsatellite polymorphism and genetic distances between the dog, red fox and arctic fox. J. Anim. Breed. Genet. 120 (2003), 88-94

KLUKOWSKA, J.; SZYDŁOWSKI, M.; ŚWITOŃSKI, M.:

Linkage of the canine-derived microsatellites in the red fox (Vulpes vulpes) and arctic fox (Alopex lagopus) genomes. Hereditas 137 (2002), 234-236

LINGAAS, F.; AARSKAUG, T.; GERLACH, J. A.; JUNEJA, R. K.; FREDHOLM, M.; SAMPSON, J.; SUTER, N.; HOLMES, N. G.; BINNS, M. M.; RYDER, E. J.; VAN HAERINGEN, W. A.; VENTA, P. J.; BROUILLETTE, J.

A.; YUZBASIYAN-GURKAN, V.; WILTON, A. N.; BREDBACKA, P.; KOSKINEN, M.; DUNNER, S.; PARRA,

D.; SCHMUTZ, S.; SCHELLING, C.; SCHLA“" PFER, J.; DOLF, G.: A canine linkage map: 39 linkage groups. J. Anim. Breed. Genet. 118 (2001), 3-20

LINGAAS, F.; SORENSEN, A.; JUNEJA, R.K.; JOHANSSON, S.; FREDHOLM, M.; WINTERO, A.K.; SAMPSON, J.; MELLERSH, C.S.; CURZON, A.; HOLMES, N.G.; BINNS, M.M.; DICKENS, H.F.; RYDER, E.J.; GERLACH, J.; BAUMLE, E.; DOLF, G.: Towards construction of a canine linkage map: Establishment of 16 linkage groups. Mamm. Genome 8 (1997), 218-221

MELLERSH, C.S.; HITTE, C.; RICHMAN, M.; VIGNAUX, F.; PRIAT, C.; JOUQUAND, S.; WERNER, P.;

ANDRE, C.; DEROSE, S.; PATTERSON, D.F.; OSTRANDER, E.A.; GALIBERT, F.: An integrated linkage-radiation hybrid map of the canine genome. Mamm. Genome 11 (2000), 120-130

MELLERSH, C.S.; LANGSTON, A.A.; ACLAND, G.M.; FLEMING, M.A.; RAY, K.; WIEGAND, N.A.; FRANCISCO, L.V.; GIBBS, M.; AGUIRRE, G.D.; OSTRANDER, E.A.: A linkage map of the canine genome. Genomics 46 (1997), 326-336

NEFF, M. W.; BROMAN, K. W.; MELLERSH, C. S.; RAY, K.; ACLAND, G. M. ; AGUIRRE, G. D.; ZIEGLEJ, S.; OSTRANDER, E. A.; RINE, J.: A Second-Generation Genetic Linkage Map of the Domestic Dog, Canis familiaris. Genetics 151 (1999), 803-820

NIE, W.; WANG, J.; PERELMAN, P.; GRAPHODATSKY, A.S.; YANG, F.: Comparative chromosome painting defines the karyotypic relationships among the domestic dog, Chinese raccoon dog and Japanese raccoon dog. Chromosome Res. 11 (2003), 735-740 
ROGALSKA-NIZNIK, N.; SZCZERBAL, I.; DOLF, G.; SCHLÄPFER, J.; SCHELLING, C.; ŚWITOŃSKI, M.: Canine-derived cosmid probes containing microsatellites can be used in physical map of the arctic fox (Alopex lagopus) and the Chinese raccoon dog (Nyctereutes procyonides procyonides) genomes. J. Hered. 94:1 (2003), 89-93

SZCZERBAL, I.; NOWACKA-WOSZUK, J.; RACKA, M.; KLUKOWSKA-ROETZLER, J.; SCHELLING, C.; DOLF, G.; SWITONSKI, M.:

Cytogenetic mapping and STR polymorphism of two candidate genes (DRD2 and HTR1D) for behaviour traits in four canids. Archiv für Tierzucht 50 (2007) 412-417

SZCZERBAL, I.; ROGALSKA-NIZNIK, N.; SCHELLING, C.; SCHLAPFER, J.; DOLF, G.; ŚWITOŃSKI, M.:

Development of a cytogenetic map for the Chinese raccoon dog (Nyctereutes procyonoides procyonoides) and the arctic fox (Alopex lagopus) genomes, using canine-derived microsatellite probes. Cytogenet. Genome Res. 102 (2003), 267-271

ŚLASKA, B.; JEŻEWSKA, G.; ZIĘBA, G.:

Preliminary results of application of chosen DNA sequence primers of Canis familiaris in amplification of Nyctereutes procyonoides genom parallelis loci. [In Polish]. Roczniki Naukowe Polskiego Towarzystwa Zootechnicznego 1:2 (2005), 253-260

VOORRIPS, R.E.:

MapChart: Software for the graphical presentation of linkage maps and QTLs. The Journal of Heredity 93 (1) (2002), 77-78

WERNER, P.; MELLERSH, C.S.; RADUCHA, M.G.; DEROSE, S.; ACLAND, G.M.;

PROCIUK, U.; WIEGAND, N.; AGUIRRE, G.D.; HENTHORN, P.S.; PATTERSON, D.F.; OSTRANDER, E.A.: Anchoring of canine linkage groups with chromosome-specific markers. Mamm. Genome 10 (1999), 814823

YANG, F.; MILNE, B. S.; SCHELliNG, C.; DOLF, G.; SCHLAPFER, J.; ŚWITOŃSKI, M.; LADON, D.; PIENKOWSKA, A.; BOSMA, A. A.; SARGAND, D.; FERGUSON-SMITH, M. A.:

The red fox and dog comparative chromosome map facilitates chromosomal assignment of canine cosmid clones containing highly polymorphic microsatellite sequences. Chrom. Res. 8 (2000), 93-100

YUZBASIYAN-GURKAN, V.; BLANTON, S.H.; CAO Y.; FERGUSON, P.; LI J., VENTA, P.J.; BREWER, G.J: Linkage of a microsatellite marker to the canine copper toxicosis locus in Bedlingston terriers. Am. J. Vet. Res. 58:1 (1997), 23-7

Received: 2006-12-04

Accepted: 2007-11-14

Authors addresses:

Prof. Dr. habil. GRAŻYNA JEŻEWSKA*

Dr. habil. GRZEGORZ ZIĘBA

Dr. BRYGIDA ŚLASKA*

Department of Biological Bases of Animal Production,

University of Agriculture,

Lublin, 20-950, Akademicka 13 st. Poland

Dr. MARIUSZ PIERZCHAŁA

Institute of Genetics and Animal Breeding,

Polish Academy of Siences,

Jastrzebiec, 05-552 Wolka Kosowska, Poland

*Corresponding author

email: grazyna.jezewska@ar.lublin.pl

brygida.slaska@ar.lublin.pl 